\title{
Metabolic hormones regulate insulin-like growth factor binding protein-1 mRNA levels in primary cultured salmon hepatocytes; lack of inhibition by insulin
}

\author{
A L Pierce ${ }^{1,2}$, M Shimizu ${ }^{1,2}$, L Felli ${ }^{1,2}$, P Swanson ${ }^{1,2}$ and W W Dickhoff ${ }^{1,2}$ \\ ${ }^{1}$ Integrative Fish Biology Program, Northwest Fisheries Science Center, National Marine Fisheries Service, 2725 Montlake Boulevard E., Seattle, Washington \\ 98112, USA \\ ${ }^{2}$ School of Aquatic and Fishery Sciences, University of Washington, Seattle, Washington 98195, USA \\ (Requests for offprints should be addressed to A L Pierce who is now at Hawaii Institute of Marine Biology, PO Box 1346, Kaneohe, Hawaii 96744-1346, USA; \\ Email: piercea@hawaii.edu)
}

\begin{abstract}
IGF-binding proteins (IGFBPs) modulate the effects of the IGFs, major stimulators of vertebrate growth and development. In mammals, IGFBP-1 inhibits the actions of IGF-I. Rapid increases in circulating IGFBP-1 occur during catabolic states. Insulin and glucocorticoids are the primary regulators of circulating IGFBP-1 in mammals. Insulin inhibits and glucocorticoids stimulate hepatocyte $I G F B P$ - 1 gene expression and production. A $22 \mathrm{kDa}$ IGFBP in salmon blood also increases during catabolic states and has recently been identified as an IGFBP-1 homolog. We examined the hormonal regulation of salmon IGFBP-1 mRNA levels and protein secretion in primary cultured salmon hepatocytes. The glucocorticoid agonist dexamethasone progressively increased hepatocyte IGFBP-1 mRNA levels (eightfold) and medium IGFBP-1 immunoreactivity over concentrations comparable with stressed
\end{abstract}

circulating cortisol levels $\left(10^{-9}-10^{-6} \mathrm{M}\right)$. GH progressively reduced IGFBP-1 mRNA levels (0.3-fold) and medium IGFBP-1 immunoreactivity over physiological concentrations $\left(5 \times 10^{-11}-5 \times 10^{-9} \mathrm{M}\right)$. Unexpectedly, insulin slightly increased hepatocyte IGFBP-1 mRNA (1-4-fold) and did not change medium IGFBP-1 immunoreactivity over physiological concentrations and above $\left(10^{-9}-10^{-6} \mathrm{M}\right)$. Triiodothyronine had no effect on hepatocyte IGFBP-1 mRNA, whereas glucagon increased IGFBP-1 mRNA (2·2-fold) at supraphysiological concentrations $\left(10^{-6} \mathrm{M}\right)$. This study suggests that the major inhibitory role of insulin in the regulation of liver IGFBP1 production in mammals is not found in salmon. However, regulation of salmon liver IGFBP-1 production by other metabolic hormones is similar to what is found in mammals.

Journal of Endocrinology (2006) 191, 379-386

\section{Introduction}

The mitogenic insulin-like growth factors (IGF-I and IGF-II) circulate bound to members of a family of IGF-binding proteins (IGFBPs). In mammals, six IGFBPs have been identified, which can both enhance and inhibit the actions of the IGFs (Duan 2002, Firth \& Baxter 2002, Frystyk 2004). Out of the IGFBPs studied to date, IGFBP-1 is unique in that it responds rapidly and strongly to metabolic status and stress (Lee et al. 1993, 1997). Plasma levels routinely fluctuate more than tenfold daily, increasing rapidly during fasting, stress, and in other catabolic states, and decreasing after meals. IGFBP-1 inhibits the actions of IGF-I in vitro and in vivo by decreasing levels of free IGF-I available to bind the IGF-I receptor. Plasma IGFBP-1 levels are determined by liver production of the protein, which has a short half life in the circulation.

In postnatal mammals, plasma IGFBP-1 levels are regulated in accordance with metabolic status through effects of metabolic hormones on hepatocyte IGFBP-1 gene transcription. Insulin plays a primary role by strongly inhibiting
IGFBP-1 production (Unterman et al. 1991, Lee et al. 1993, 1997, Frystyk 2004). Negative regulation of hepatocyte IGFBP-1 production by insulin accounts for the postprandial decrease in plasma IGFBP-1 levels, the effects of diet composition on plasma IGFBP-1 levels, and the inverse correlation between circulating insulin and IGFBP-1 levels. Glucocorticoids stimulate hepatocyte IGFBP-1 gene transcription and increase circulating IGFBP-1 levels; however, suppression of IGFBP-1 production by insulin dominates stimulation by glucocorticoids (Unterman et al. 1991). The effects of insulin and cortisol on IGFBP-1 gene transcription are mediated by contiguous negative and positive insulin and glucocorticoid-response elements in mammalian IGFBP-1 promoters respectively (Goswami et al. 1994, Suwanichkul et al. 1994). While insulin and glucocorticoids are thought to be the primary hormonal regulators of liver IGFBP-1 production, other anabolic and catabolic hormones also play roles. In general, growth hormone $(\mathrm{GH})$ decreases and glucagon increases hepatocyte IGFBP-1 mRNA levels (Denver \& Nicoll 1994, Kachra et al. 1994, Thissen et al. 
1994). Cytokines directly induce IGFBP-1 (Lee et al. 1997). Possibly indirect induction by thyroid hormones and catecholamines have been reported (Lee et al. 1997). In addition to hormonal regulation, primary hepatocyte IGFBP-1 mRNA levels are directly increased by low amino acid levels (Thissen et al. 1994) and by hypoxia (Popovici et al. 2001, Scharf et al. 2005).

Both the regulation of IGFBP-1 by metabolic status and stress and its function as an inhibitor of IGF actions appear to be conserved between teleost fishes and other vertebrates (Kelley et al. 2001, 2002, Shimizu et al. 2005, 2006, Wood et al. 2005). IGFBPs are found in western ligand blots of fish plasma. Lower molecular weight (20-30 kDa) IGFBPs are increased in catabolic states in a number of fish species, suggesting that one of these bands may correspond to IGFBP-1 (Siharath et al. 1996, Park et al. 2000, Kelley et al. 2001, Kajimura et al. 2003). However, until recently, definitive identification of these proteins has been lacking due to the absence of molecular sequence data. Recent studies have shown that liver IGFBP-1 gene transcription is induced by hypoxia in adult gobies (Gillichthyes mirabilis) and zebrafish (Danio reiro) (Gracey et al. 2001, Maures \& Duan 2002), that the induction of IGFBP-1 partially underlies hypoxiainduced growth retardation in zebrafish embryos (Kajimura et al. 2005) and that the zebrafish IGFBP-1 promoter contains a functional hypoxia-response element (Kajimura et al. 2006). These findings suggest that both the growth-inhibitory role and the regulation of IGFBP-1 may be highly conserved among vertebrates. Nucleotide sequence data reveal that a $22 \mathrm{kDa}$ IGFBP in Chinook salmon (Oncorhynchus tshawytscha) plasma is an IGFBP-1 homolog (Shimizu et al. 2005). Salmon IGFBP-1 is most highly expressed in the liver, suggesting a hepatic source for circulating IGFBP-1. In order to elucidate endocrine mechanisms in the metabolic regulation of liver IGFBP-1 production in salmon, we examined the effects of metabolic hormones on IGFBP-1 mRNA levels and protein secretion in primary cultured coho salmon (Oncorhynchus kisutch) hepatocytes.

\section{Materials and Methods}

\section{Animals}

Coho salmon (O. kisutch) were raised in $1.3 \mathrm{~m}$ diameter cylindrical tanks with recirculated fresh water at $11-12{ }^{\circ} \mathrm{C}$ under simulated natural photoperiod at the Northwest Fisheries Science Center (Seattle, WA, USA). Fish were fed BioOregon-grower pellets at a ration of $0.6 \%$ body weight per day. For cultures, 2-year-old fish were used and fasted for 1 day prior to hepatocyte isolation to reduce potential contamination of cultures from gut contents. Data shown are from the following cultures: 10/12/02, independent cultures from three immature female fish, 143, 149, and $157 \mathrm{~g}$ for Fig. $1 \mathrm{~A}$ and $\mathrm{B} ; 12 / 7 / 02$ pooled cells from two immature male fish, 146 and $179 \mathrm{~g}$ for Fig. 3 and one replicate culture in Fig. $1 \mathrm{~B}$ and C; 6/12/04 pooled cells from two immature male fish, 262 and $275 \mathrm{~g}$ for Figs 2 and $4 \mathrm{~A}$ and $\mathrm{B} ; 8 / 13 / 05$ independent cultures from one immature male fish $349 \mathrm{~g}$ and one immature female fish $292 \mathrm{~g}$ for Fig. 1C. Experiments complied with the guidelines of the University of Washington Institutional Animal Care and Use Committee.

\section{Hepatocyte culture, RNA isolation, and $\mathrm{cDN} A$ synthesis}

Hepatocytes were isolated and cultured as previously described (Pierce et al. 2004). Cells were cultured on Falcon Primaria 24-well plates at $15^{\circ} \mathrm{C}$ in modified RPMI 1640 medium (Gibco BRL, Gaithersburg, MD, USA; buffer changed to $20 \mathrm{mM}$ HEPES, $5 \mathrm{mM} \mathrm{NaHCO}$ ). Hepatocytes were plated at a density of approximately $4 \times 10^{6}$ cells/well in the plain medium and allowed to adhere for $24 \mathrm{~h}$, and then medium was changed to test medium containing hormones. Cultures were stopped $18 \mathrm{~h}$ later by adding Tri-Reagent (Molecular Research Center (MRC), Cincinnati, OH, USA) to wells. RNA was isolated following the MRC protocol with bromochloropropane as the phase separation reagent and two 75\% ethanol washes. RNA was quantitated by spectrophotometry (260:280 ratios $1 \cdot 8-2 \cdot 0)$, and diluted to $10 \mathrm{ng} / \mu \mathrm{l}$. First-strand cDNA was synthesized in $15 \mu \mathrm{l}$ reverse transcription (RT) reactions with $3 \mu \mathrm{l}$ RNA template, $2.5 \mathrm{U} / \mu \mathrm{l}$ SuperScript II reverse transcriptase (Invitrogen), $5 \mu \mathrm{M}$ random hexamer primers, $500 \mu \mathrm{M}$ dNTPs, $0 \cdot 4 \mathrm{U} / \mu \mathrm{l}$ RNase inhibitor (Applied Biosystems, Inc. (ABI), Foster City, CA, USA), $10 \mathrm{mM} \mathrm{DTT}$, and $1 \times \mathrm{RT}$ buffer, incubated at $25^{\circ} \mathrm{C}$ for $10 \mathrm{~min}, 48^{\circ} \mathrm{C}$ for $60 \mathrm{~min}$, and $95^{\circ} \mathrm{C}$ for $5 \mathrm{~min}$.

\section{Hormones}

Native coho salmon GH was purified by HPLC (RandWeaver \& Kawauchi 1992). Native coho salmon insulin was a generous gift from Dr Erika Plisetskaya (University of Washington, Seattle). Triiodothyronine $\left(\mathrm{T}_{3}\right)$, water-soluble dexamethasone (2-hydroxypropyl- $\beta$-cyclodextrin encapsulated), native bovine insulin, and native bovine glucagon were purchased from Sigma.

\section{Real-time quantitative RT-PCR (qPCR) and radioimmunoassays}

Hepatocyte IGFBP-1 mRNA levels were quantified using a TaqMan probe qPCR assay with the amplicon in the region of the transcript covering the predicted exon 2/exon 3 junction (Table 1). PCR efficiency was reasonable (slope $=-3 \cdot 642$; Table 1) and equal between input cDNA template from Chinook and coho salmon liver and coho salmon primary cultured hepatocytes. No amplification was observed in wells containing no template, coho salmon genomic DNA, or experimental hepatocyte culture and liver cDNA preparations in which the RT enzyme was omitted from the $\mathrm{RT}$ reaction. No bias across the PCR plate was found when 

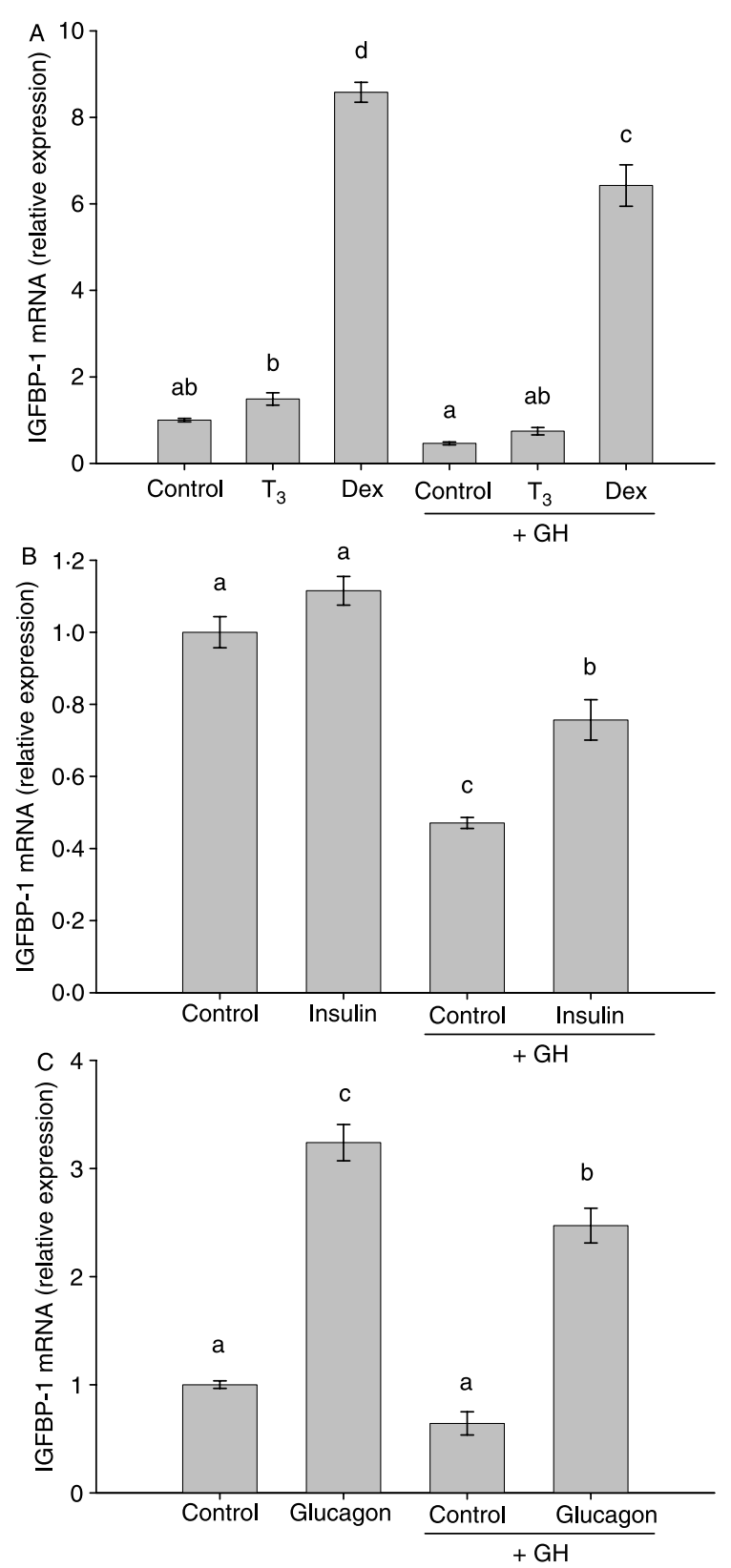

Figure 1 Effects of metabolic hormones on IGFBP-1 mRNA levels in primary cultured salmon hepatocytes. (A) Effects of dexamethasone (Dex, cyclodextrin encapsulated, $10^{-6} \mathrm{M}$ ), triiodothyronine $\left(\mathrm{T}_{3}\right.$, $\left.10^{-7} \mathrm{M}\right)$, and growth hormone $\left(\mathrm{GH}\right.$, coho salmon, $\left.5 \times 10^{-9} \mathrm{M}\right)$. Data shown are from three independent cultures, response level normalized to the average response to Dex for all cultures, $n=11-12$ wells per bar. (B) Effects of insulin $\left(10^{-6} \mathrm{M}\right)$ and $\mathrm{GH}$. Data shown are from four independent cultures (three with bovine insulin, one with salmon insulin), response level normalized to the average response to $\mathrm{GH}$ for all cultures, $n=16$ wells per bar. (C) Effects of glucagon (bovine, $10^{-6} \mathrm{M}$ ) and $\mathrm{GH}$. Data shown are from three independent cultures, response level normalized to the average response to glucagon for all cultures, $n=12$ wells per bar. In all panels, error bars show standard error and bars not sharing a superscript letter differ significantly $(P<0 \cdot 05$, Bonferroni-Dunn test).

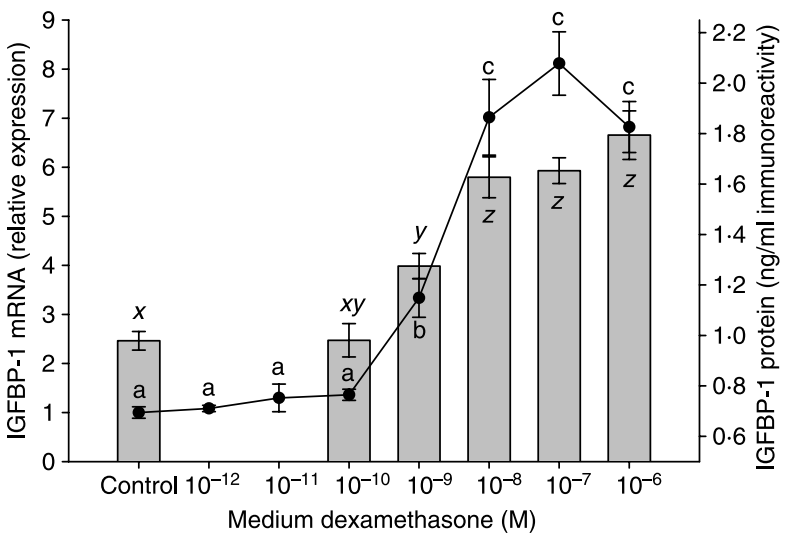

Figure 2 Effect of medium dexamethasone concentration on cellular IGFBP-1 mRNA levels (points), and conditioned medium IGFBP-1 protein immunoreactivity (bars) in primary cultured salmon hepatocytes. Error bars show standard error; $n=5-6$ wells per point or bar; points or bars not sharing a superscript letter differ significantly $(P<0 \cdot 05$, Bonferroni-Dunn test).

the same cDNA was loaded across an entire row. Salmon growth hormone receptor (GHR) mRNA levels were quantified using a TaqMan probe qPCR assay in the extracellular domain as previously described (Fukada et al. 2004). mRNA level data were normalized to the mRNA level of acidic ribosomal phosphoprotein P0 (ARP), using an efficiency corrected relative expression technique (Pierce et al. 2004). To minimize the effects of variability in RNA quantification, RNA quality, and RT efficiency, RNA from each cell culture well was reverse transcribed once and the qPCR assays for IGFBP-1, ARP, and GHR (where measured) run from the same cDNA preparation. A single replicate of each PCR was run. Assays were run in 96-well format on an ABI $7700 \mathrm{qPCR}$ machine. All samples to be compared were run on the same PCR plate. As a standard, a fivefold serial dilution from a coho salmon liver (highest concentration $100 \mathrm{ng} / \mathrm{ml}$ RNA input to RT reaction, four standards, three replicate wells per standard) was run on each plate.

Medium IGFBP-1 protein levels were measured with a newly developed RIA (Shimizu et al. 2006). Some nonparallelism was observed in serial dilutions of hepatocyte-conditioned medium versus assay standards and serial

Table 1 Primer and probe sequences for salmon IGFBP-1 TaqMan RT-PCR assay
Sequence $\left(5^{\prime}-3^{\prime}\right)$

Element

F primer R primer Probe
Amplicon; PCR efficiency

$68 \mathrm{bp}$ $0 \cdot 879 \pm 0 \cdot 007$

\section{AACACCATCCGCAAGAAACTG \\ ATCCAGAGCTGCATGCA CACATTG-Tamra}

$F$, forward; $R$, reverse. 
dilution of Chinook salmon serum (data not shown). Therefore, measurements of IGFBP-1 protein levels in hepatocyte culture medium are designated as immunoreactivity and should only be used for relative comparisons.

\section{Data analysis}

mRNA levels were expressed relative to the control treatment for each fish or hepatocyte pool. In the factorial experiments (Fig. 1), as the pattern of responses between different cultures was always similar, but the magnitude of responses sometimes differed, the data from each culture was normalized to the average response level of all cultures. Treatment and fish effects were examined by one- or two-way ANOVA followed by the Bonferroni-Dunn test. Results were considered statistically significant at $P<0 \cdot 05$.

\section{Results}

Dexamethasone $\left(10^{-6} \mathrm{M}\right)$ strongly increased IGFBP-1 mRNA levels in salmon hepatocytes (Fig. 1A). The increase in IGFBP-1 mRNA levels was substantial (12·1-, 7·9-, and $5 \cdot 7$-fold). After normalization to the average dexamethasone response level, there were no significant differences between cultures $(n=3)$. GH $\left(5 \times 10^{-9} \mathrm{M}\right)$ significantly reduced dexamethasone-stimulated IGFBP-1 mRNA levels. GH tended to reduce basal IGFBP-1 mRNA levels; however, the reduction was not significant $(P=0 \cdot 112)$. Triiodothyronine $\left(10^{-7} \mathrm{M}\right)$ did not significantly affect IGFBP-1 mRNA levels alone or in combination with $\mathrm{GH}$.

A marginally nonsignificant increase in IGFBP-1 mRNA levels occurred with insulin treatment $(P=0 \cdot 054$; Fig. 1B). Suppression of IGFBP-1 mRNA levels by insulin was not found in four independent cultures, using both bovine insulin (three cultures) and salmon insulin (one culture). GH significantly decreased IGFBP-1 mRNA levels in these cultures (to 0.30-, 0·35-, 0.57-, and 0.67-fold control levels). After normalization to the average $\mathrm{GH}$ response level, there were no significant differences between cultures. Insulin significantly attenuated the GH suppression of IGFBP-1 mRNA levels, but did not restore IGFBP-1 mRNA to control levels.

Glucagon $\left(10^{-6} \mathrm{M}\right)$ increased IGFBP-1 mRNA levels (Fig. 1C). The increase in IGFBP-1 mRNA levels with glucagon was less than that with dexamethasone (2*4-, 3·6-, and $3 \cdot 8$-fold in three independent cultures). GH significantly reduced glucagon-stimulated IGFBP-1 mRNA levels. Once again, a nonsignificant reduction in basal IGFBP-1 mRNA levels was consistently found with $\mathrm{GH}(P=0 \cdot 0552)$.

Dexamethasone increased IGFBP-1 mRNA levels in a concentration-dependent manner (Fig. 2A). The increase over control levels became significant at $10^{-9} \mathrm{M}$ and reached maximal levels of $8 \cdot 1$-fold control levels at $10^{-7} \mathrm{M}$. Medium IGFBP-1 immunoreactivity levels increased with increasing dexamethasone concentration in a similar concentration-dependent manner, becoming elevated versus controls at $10^{-9} \mathrm{M}$ and maximal at $10^{-6} \mathrm{M}$. A strong positive correlation was found between cellular IGFBP-1 mRNA levels and medium IGFBP-1 protein immunoreactivity in the dexamethasone concentration-response study $\left(r^{2}=0 \cdot 710\right)$.

$\mathrm{GH}\left(5 \times 10^{-9} \mathrm{M}\right)$ consistently reduced both basal and hormone-stimulated IGFBP-1 mRNA levels in survey experiments, although this effect was not always statistically significant. To examine regulation by $\mathrm{GH}$ more closely, a concentration-response study was conducted. GH reduced IGFBP-1 mRNA levels in a concentration-dependent manner (Fig. 3). The decrease versus control levels became significant at $2 \cdot 5 \times 10^{-10} \mathrm{M} \mathrm{GH}$ and attained a maximum reduction of $0 \cdot 32$-fold control levels at $5 \times 10^{-7} \mathrm{M} \mathrm{GH}$. Medium IGFBP-1 immunoreactivity levels decreased with increasing $\mathrm{GH}$ concentrations from $5 \times 10^{-11}$ to $2 \cdot 5 \times 10^{-9} \mathrm{M}$. A positive correlation was found between cellular IGFBP-1 mRNA level and medium IGFBP-1 protein immunoreactivity in the $\mathrm{GH}$ concentration-response study $\left(r^{2}=0 \cdot 456\right)$.

The lack of inhibition of IGFBP-1 mRNA levels by insulin was confirmed in a concentration-response study using salmon insulin (Fig. 4A). Insulin significantly increased IGFBP-1 mRNA levels at $10^{-8}$ and $10^{-7} \mathrm{M}$; maximum induction was $1 \cdot 38$-fold control levels. No significant effect of insulin treatment on medium IGFBP-1 immunoreactivity was found (ANOVA, $P=0 \cdot 2821$ ). No significant correlation was found between cellular IGFBP-1 mRNA level and medium IGFBP-1 protein immunoreactivity in the insulin concentration-response study. As expected, insulin significantly reduced mRNA levels of the salmon GHR in these cells (Pierce et al. 2005a), showing that cells were able to respond to insulin (Fig. 4B).

A concentration-response study with glucagon found a significant induction $\left(2 \cdot 17\right.$-fold controls) only at $10^{-6} \mathrm{M}$ glucagon (Fig. 5). Lower glucagon concentrations did not significantly affect IGFBP-1 gene mRNA levels.

The $C_{\mathrm{T}}$ for ARP did not vary between treatments in any experiment, indicating that treatments did not affect our reference gene.

\section{Discussion}

The glucocorticoid receptor agonist dexamethasone strongly increased IGFBP-1 mRNA levels in cultured salmon hepatocytes and increased IGFBP-1 immunoreactivity in conditioned medium. This result is consistent with previous studies in fish. Only a few previous fish studies have positively identified IGFBP-1. In zebrafish, fasting strongly increased liver IGFBP-1 mRNA levels (Maures \& Duan 2002). In Chinook salmon, fasting and seawater transfer caused increases in plasma levels of a $22 \mathrm{kDa}$ IGFBP on western ligand blots; this band was positively identified as salmon IGFBP-1 (Shimizu et al. 2005). Cortisol would be expected to increase during fasting and seawater transfer. A larger number of studies have used western ligand blotting without 


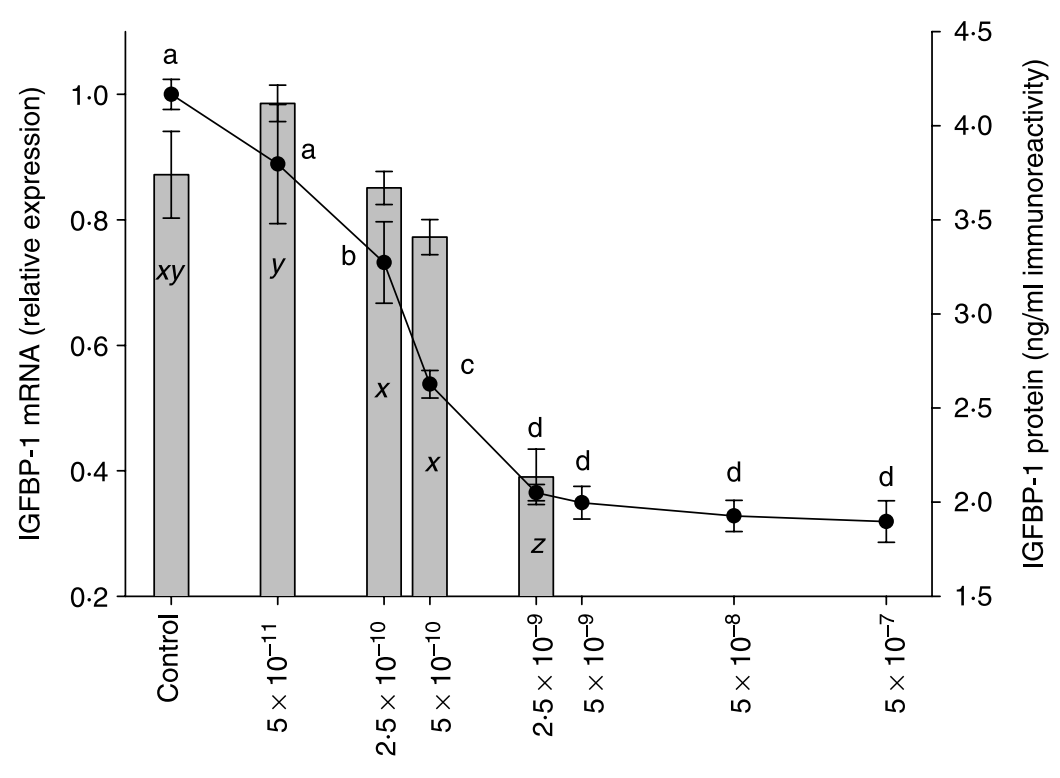

Medium growth hormone (M)

Figure 3 Effect of medium GH concentration on IGFBP-1 mRNA levels (points), and conditioned medium IGFBP-1 protein immunoreactivity (bars) in primary cultured salmon hepatocytes. Error bars show standard error; $n=5-6$ wells per point or bar; points or bars not sharing a superscript letter differ significantly $(P<0 \cdot 05$, Bonferroni-Dunn test).

positive identification of IGFBP bands. In tilapia, cortisol injection increased plasma levels of 22 and $28 \mathrm{kDa}$ IGFBPs (Kajimura et al. 2003). In channel catfish, dietary cortisol supplementation increased plasma levels of a $20 \mathrm{kDa}$ IGFBP (Peterson \& Small 2005). In gobies, fasting and experimentally induced diabetes caused increases in plasma levels of cortisol and 24 and $30 \mathrm{kDa}$ IGFBPs, whereas in jack mackerel, stress caused increases in plasma levels of cortisol and 24 and $30 \mathrm{kDa}$ IGFBPs (Kelley et al. 2001). In striped bass, fasting strongly increased plasma levels of a $25 \mathrm{kDa}$ IGFBP (Siharath et al. 1996). The results of the present study support the proposal that the increase in IGFBP-1 found in these stressful physiological states is mediated by cortisol stimulation of liver IGFBP-1 production and that this regulation is highly conserved among fishes (Kelley et al. 2001). Further, our results suggest that at least one of the lower molecular weight IGFBPs on ligand blots is IGFBP-1.

Glucocorticoids directly increase hepatocyte IGFBP-1 production and increase circulating IGFBP-1 levels in mammals (Unterman et al. 1991, Lee et al. 1997). The glucocorticoid effect on IGFBP-1 is mediated by a glucocorticoid response element in the promoter of mammalian IGFBP-1 genes (Goswami et al. 1994, Suwanichkul et al. 1994). It is not known if fish IGFBP-1 promoters contain such an element. In mammals, IGFBP-1 inhibits IGF actions and reduces growth (Firth \& Baxter 2002, Frystyk 2004). Stress and cortisol treatments reduce growth in fishes (Barton \& Iwama 1991, Peterson \& Small 2005). Recent studies in zebrafish show that elevations in IGFBP-1 mRNA levels cause growth retardation during zebrafish development (Kajimura et al. 2005). Thus, the induction of IGFBP-1 by cortisol is likely to be part of the mechanism by which stress inhibits growth in salmon and other fishes. Hypoxia increases hepatic IGFBP-1 mRNA levels in adult gobies and zebrafish (Gracey et al. 2001, Maures \& Duan 2002). This effect might be mediated by cortisol. However, in mammalian hepatocyte culture, hypoxia directly increases hepatocyte IGFBP-1 mRNA levels (Popovici et al. 2001, Scharf et al. 2005). Further, the zebrafish IGFBP-1 promoter contains a functional hypoxia-response element, indicating that cellular pathways for direct hypoxia induction of IGFBP-1 exist in fishes (Kajimura et al. 2006). A 21 kDA IGFBP increased during gradual seawater adaptation in rainbow trout; however, cortisol increased only slightly and transiently (Shepherd et al. 2005). Further studies are required to evaluate the role of cortisol in the regulation of fish IGFBP-1 by various physiological stressors.

Dexamethasone concentrations of $10^{-12}-10^{-10} \mathrm{M}$ did not change IGFBP-1 mRNA or medium protein levels. The full range of regulation occurred from $10^{-10}$ to $10^{-8} \mathrm{M}$, similar to the range of cortisol from basal to stressed levels respectively (Barton \& Iwama 1991). However, in a previous study using the same culture conditions and hormones, dexamethasone substantially reduced GH-stimulated IGF-I mRNA levels at $10^{-12} \mathrm{M}$, and maximal inhibition of the IGF-I response to GH occurred at $10^{-8} \mathrm{M}$ dexamethasone and above (Pierce $e$ t al. 2005a). Recently, two functional glucocorticoid receptors with different sensitivities of transactivational activity in response to cortisol and dexamethasone were characterized in rainbow trout (Bury et al. 2003). The differing 

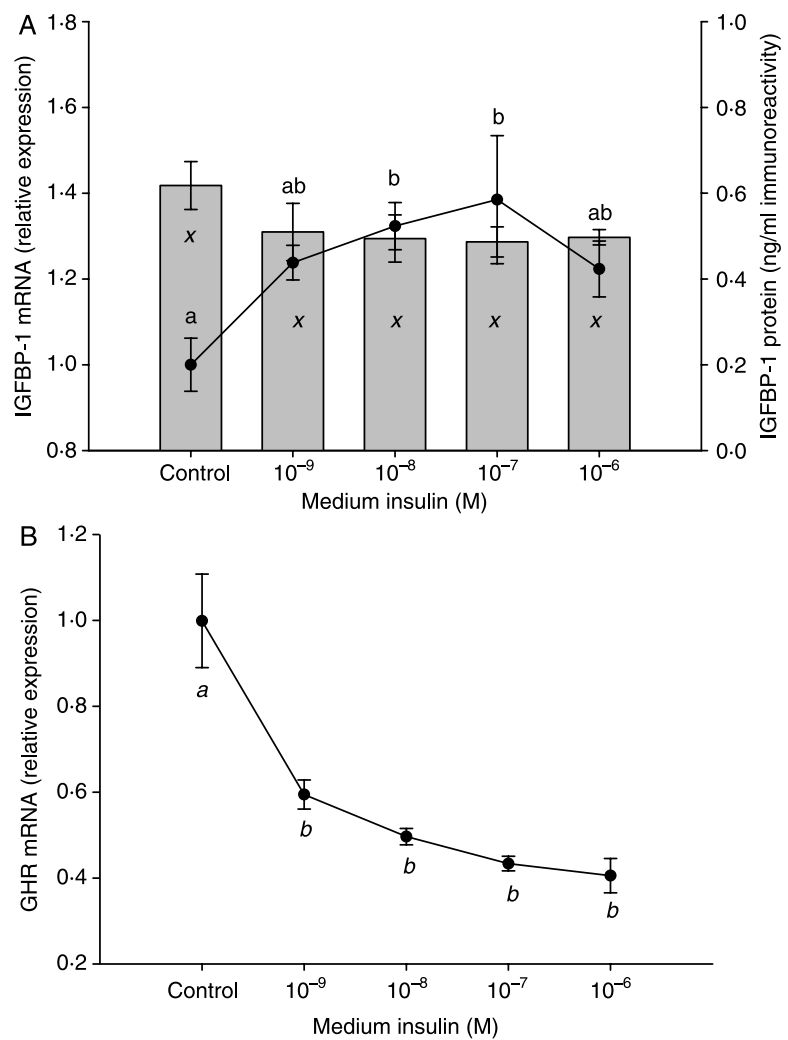

Figure 4 (A) Effect of medium insulin concentration on IGFBP-1 mRNA levels (points), and conditioned medium IGFBP-1 protein immunoreactivity (bars) in primary cultured salmon hepatocytes. (B) Effect of medium insulin concentration on growth hormone receptor (GHR) mRNA levels in primary cultured salmon hepatocytes. In both panels: error bars show standard error; $n=4-5$ wells per point or bar; points or bars not sharing a superscript letter differ significantly $(P<0 \cdot 05$, Bonferroni-Dunn test).

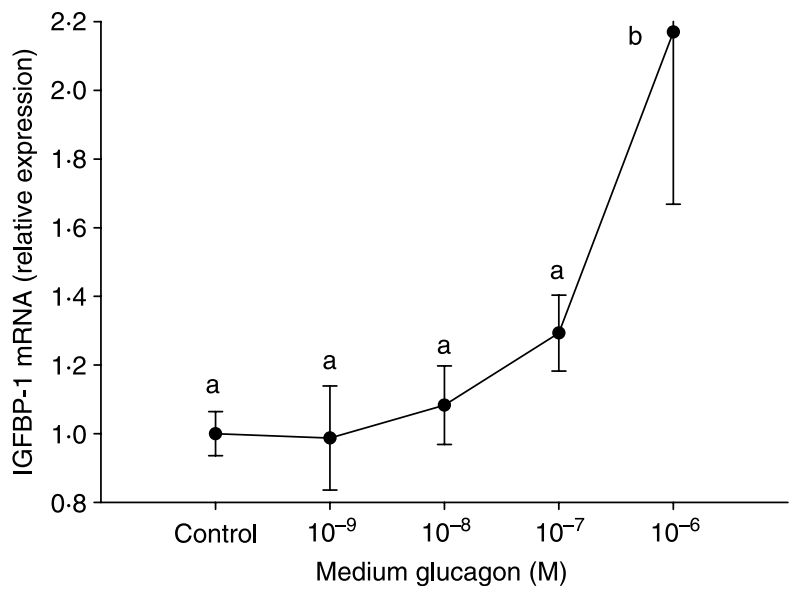

Figure 5 Effect of medium glucagon concentration on IGFBP-1 mRNA levels in primary cultured salmon hepatocytes. Error bars show standard error; $n=4-5$ wells per point; points not sharing a superscript letter differ significantly $(P<0 \cdot 05$, Bonferroni-Dunn test). concentration-response curves for the IGF-I and IGFBP-1 response to dexamethasone are consistent with the possibility that different glucocorticoid receptors may mediate these effects. Alternatively, the difference in sensitivity may occur downstream from the receptor.

GH inhibited IGFBP-1 mRNA levels to approximately onethird of control levels in cultured salmon hepatocytes. Inhibition of IGFBP-1 mRNA levels by GH occurred at $0.25 \mathrm{nM}$ $(5.5 \mathrm{ng} / \mathrm{ml})$ and above, comparable with circulating concentrations during GH secretion episodes (e.g. Pierce et al. 2005b). GH $(2 \cdot 5 \mathrm{nM})$ also decreased conditioned medium IGFBP-1 immunoreactivity. GH significantly attenuated dexamethasonestimulated IGFBP-1 mRNA levels, but did not reduce it to control levels, indicating that neither effect is completely dominant over the other. Negative regulation of a $20 \mathrm{kDa}$ IGFBP by $\mathrm{GH}$ has been described in tilapia; this band was strongly increased by hypophysectomy and reduced by $\mathrm{GH}$ replacement (Park et al. 2000). Based on regulation by GH, this band functionally corresponds to tilapia IGFBP-1. While initially controversial, it is now clear that $\mathrm{GH}$ reduces hepatocyte IGFBP-1 mRNA levels and protein secretion in mammals (Norrelund et al. 1999). However, inhibition of IGFBP-1 by $\mathrm{GH}$ is not thought to be of great physiological importance in mammals, because inhibition by insulin is much stronger (Lee et al. 1997). Based on the limited comparative data now available, inhibition of liver IGFBP-1 production by GH appears highly conserved among vertebrates. The lack of an insulin effect in coho salmon suggests that inhibition of IGFBP-1 by GH may be of greater physiological significance in this species. Inhibition of IGFBP-1 by GH is consistent with the growth stimulatory role of GH. Further, in mammals, IGFBP-1 may reduce negative feedback from free IGF-I on $\mathrm{GH}$ secretion, linking $\mathrm{GH}$ and IGFBP-1 in a negative feedback loop (Frystyk 2004). Negative feedback from IGF-I on $\mathrm{GH}$ secretion has also been demonstrated in fish (Perez-Sanchez et al. 1992).

Insulin did not change or slightly increased IGFBP-1 mRNA levels in cultured salmon hepatocytes. This result was unexpected; in mammals, insulin strongly represses liver IGFBP-1 mRNA levels in vivo and in vitro. The lack of repression of IGFBP-1 mRNA levels by insulin cannot be attributed to an anomalous culture, since it was found in five independent cell preparations, or to unresponsive cells, since insulin was effective at reducing GHR mRNA levels and inhibiting the IGF-I response to GH in these cultures (Fig. 4, Pierce et al. 2005a). Bovine and salmon insulin had similar effects, suggesting that the lack of repression of IGFBP-1 by insulin was not due to the use of heterologous insulin. The lack of repression by insulin was confirmed at the protein level; insulin did not significantly repress conditioned medium IGFBP-1 immunoreactivity levels. Cultured salmon hepatocytes responded as expected in terms of IGFBP-1 response to dexamethasone, GH, and glucagon. Therefore, we believe that the most reasonable interpretation of our results is that the role of insulin in the regulation of hepatocyte IGFBP-1 mRNA levels differs between salmon and mammals. In vivo, insulin increased rapidly and strongly after 
a meal in coho salmon, whereas IGFBP-1 decreased slowly and moderately ( $M$ Shimizu, unpublished observations). In the goby, removal of the endocrine pancreas resulted in the absence of insulin, and caused increases in plasma levels of glucose, cortisol, and a $24 \mathrm{kDa}$ IGFBP (putative goby IGFBP1 ), all of which were normalized by insulin injection (Kelley et al. 2001). Thus, the increase in putative goby IGFBP-1 can be explained by regulation by cortisol only. However, direct regulation of hepatocyte IGFBP-1 production by insulin must be examined in more fish species before any conclusions can be drawn about how widespread the lack of insulin regulation of IGFBP-1 may be. Further, it must be noted that the results in mammals are based on studies in humans and laboratory rodents. In other mammalian species, ligand blotting studies have found that lower-molecular weight IGFBPs (putative IGFBP-1s) sometimes did not increase as expected during catabolic states (Maxwell et al. 1998, Schmidt \& Kelley 2001).

Insulin attenuated the repression of IGFBP-1 by GH, and slightly increased basal IGFBP-1 mRNA levels at intermediate concentrations. The magnitude of these effects was much less than those of dexamethasone and GH. The effect on GH-stimulated IGFBP-1 mRNA levels may be due to insulin induction of GH resistance. Insulin reduced mRNA levels of the $\mathrm{GH}$ receptor and reduced the stimulatory effect of $\mathrm{GH}$ on IGF-I mRNA levels in salmon hepatocytes (Pierce et al. $2005 a$, Fig. 4). The slight stimulation of basal IGFBP-1 may be due to insulin influence on hepatocyte metabolism. In fish hepatocytes, insulin stimulates uptake of amino acids and glucose and modulates many aspects of metabolic substrate metabolism (Mommsen \& Plisetskaya 1991, Moon 2004).

The correlation between cellular mRNA levels and conditioned medium IGFBP-1 immunoreactivity was strong in the dexamethasone concentration-response study $\left(r^{2}=\right.$ $0 \cdot 710$ ), intermediate in the $\mathrm{GH}$ concentration-response study $\left(r^{2}=0 \cdot 456\right)$, and not significant in the insulin concentrationresponse study. This was probably due to decreasing range of variability of input data. The strong correlation when a large range of input variability was provided is consistent with regulation of salmon liver IGFBP-1 production at the level of gene transcription, as in mammals (Lee et al. 1993, 1997).

Glucagon increased IGFBP-1 mRNA levels in salmon hepatocytes, but only at $10^{-6} \mathrm{M}$, a concentration the liver would not likely experience physiologically. Glucagon increased IGFBP-1 mRNA levels and protein secretion at concentrations approximately 100 -fold lower in primary rat hepatocytes (Denver \& Nicoll 1994, Kachra et al. 1994), and the responses to dexamethasone and $\mathrm{GH}$ occurred at physiological concentrations in the present study. Therefore, the present study suggests that glucagon may not regulate salmon liver IGFBP-1 production under normal physiological conditions. The effect found at $10^{-6} \mathrm{M}$ may be mediated by an effect on hepatocyte metabolism (Moon 2004). Triiodothyronine $\left(10^{-7} \mathrm{M}\right)$ did not significantly change IGFBP-1 mRNA levels in salmon hepatocytes. Triiodothyronine increases IGFBP-1 mRNA levels in mammalian hepatoma cell lines, but may decrease it in mammalian primary hepatocytes (Kachra et al. 1994, Demori et al. 1997). These and other divergent results on IGFBP-1 regulation in mammalian cell culture may be due to differences in culture conditions. Salmon primary hepatocytes do not require medium serum or hormonal supplements to maintain cell viability.

Our studies on the regulation of GH/IGF axis components in primary salmon hepatocytes show that the role of insulin in the regulation of the GH/IGF axis in salmon is quite different from the mammalian model. In salmon hepatocytes, insulin induced GH resistance in terms of IGF-I mRNA levels (Pierce et al. 2005a), and did not reduce IGFBP-1 mRNA levels (present study). In mammals, insulin enhances GH sensitivity in terms of IGF-I gene expression, and strongly inhibits IGFBP-1 gene expression. The significance of these differences is not yet clear. The strong linkage between insulin and IGFBP-1 in mammals has led to the proposal that IGFBP-1 may play a role in glucose counter-regulation by inhibiting the metabolic effects of IGFs (Lee et al. 1997, Frystyk 2004). In fishes, glycemic control is much less stringent than in mammals (Mommsen \& Plisetskaya 1991, Kelley et al. 2001, Moon 2001). The lack of a linkage between insulin and IGFBP-1 in coho salmon is consistent with the lesser importance of glycemic control in this species. The negative regulation of IGF-I by insulin is consistent with a greater role for insulin in growth (Mommsen and Plisetskaya 1991).

\section{Acknowledgements}

We thank Dr Erika Plisetskaya for the generous gift of salmon insulin, and Dr Brian Beckman for hatchery management.

\section{Funding}

This project was supported by National Research Initiative Competitive Grant no. 2003-35206-13631 from the USDA Cooperative State Research, Education, and Extension service. Support was also provided by fellowships from the University of Washington School of Aquatic and Fishery Sciences, and grants from the Bonneville Power Administration (projects 92-022 and 93-056). The authors declare that there is no conflict of interest that would prejudice the impartiality of this scientific work. This publication was partially funded by the Joint Institute for the Study of the Atmosphere and Ocean (JISAO) under NOAA Cooperative Agreement no. NA17RJ1232, Contribution no. 1319.

\section{References}

Barton BA \& Iwama GK 1991 Physiological change in fish from stress in aquaculture with emphasis on the response and effects of corticosteriods. Annual Review of Fish Diseases 1 3-26.

Bury NR, Sturm A, Le Rouzic P, Lethimonier C, Ducouret B, Guiguen Y, Robinson-Rechavi M, Laudet V, Rafestin-Oblin ME \& Prunet P 2003 Evidence for two distinct functional glucocorticoid receptors in teleost fish. Journal of Molecular Endocrinology 31 141-156. 
Demori I, Bottazzi C, Arzani D, Voci A \& Fugassa E 1997 Regulation of IGFBP1 and -4 expression by triiodothyronine $\left(T_{3}\right)$ in cultured hepatocytes is celland gene-specific. Bollettino della Societa italiana di biologia sperimentale 73 47-53.

Denver RJ \& Nicoll CS 1994 Pancreatic hormones differentially regulate insulin-like growth factor (IGF)-I and IGF-binding protein production by primary rat hepatocytes. Journal of Endocrinology 142 299-310.

Duan C 2002 Specifying the cellular responses to IGF signals: roles of IGF-binding proteins. Journal of Endocrinology 175 41-54.

Firth SM \& Baxter RC 2002 Cellular actions of the insulin-like growth factor binding proteins. Endocrine Reviews 23 824-854.

Frystyk J 2004 Free insulin-like growth factors - measurements and relationships to growth hormone secretion and glucose homeostasis. Growth Hormone and IGF Research 14 337-375.

Fukada H, Ozaki Y, Pierce AL, Adachi S, Yamauchi K, Hara A, Swanson P \& Dickhoff WW 2004 Salmon growth hormone receptor: molecular cloning, protein expression, binding assay and gene expression. General and Comparative Endocrinology 139 61-71.

Goswami R, Lacson R, Yang E, Sam R \& Unterman T 1994 Functional analysis of glucocorticoid and insulin response sequences in the rat insulinlike growth factor-binding protein-1 promoter. Endocrinology 134 736-743.

Gracey AY, Troll JV \& Somero GN 2001 Hypoxia-induced gene expression profiling in the euryoxic fish Gillichthys mirabilis. PNAS 98 1993-1998.

Kachra Z, Yang CR, Murphy LJ \& Posner BI 1994 The regulation of insulinlike growth factor-binding protein 1 messenger ribonucleic acid in cultured rat hepatocytes: the roles of glucagon and growth hormone. Endocrinology 135 1722-1728.

Kajimura S, Hirano T, Visitacion N, Moriyama S, Aida K \& Grau EG 2003 Dual mode of cortisol action on GH/IGF-I/IGF binding proteins in the tilapia, Oreochromis mossambicus. Journal of Endocrinology 178 91-99.

Kajimura S, Aida K \& Duan C 2005 Insulin-like growth factor-binding protein-1 (IGFBP-1) mediates hypoxia-induced embryonic growth and developmental retardation. PNAS 102 1240-1245.

Kajimura S, Aida K \& Duan C 2006 Understanding hypoxia-induced gene expression in early development: in vitro and in vivo analysis of hypoxiainducible factor 1-regulated zebra fish insulin-like growth factor binding protein 1 gene expression. Molecular and Cellular Biology 26 1142-1155.

Kelley KM, Haigwood JT, Perez M \& Galima MM 2001 Serum insulin-like growth factor binding proteins (IGFBPs) as markers for anabolic/catabolic condition in fishes. Comparative Biochemistry and Physiology 129B 229-236.

Kelley KM, Schmidt KE, Berg L, Sak K, Galima MM, Gillespie C, Balogh L, Hawayek A, Reyes JA \& Jamison M 2002 Comparative endocrinology of the insulin-like growth factor-binding protein. Journal of Endocrinology 175 3-18.

Lee PD, Conover CA \& Powell DR 1993 Regulation and function of insulinlike growth factor-binding protein-1. Proceedings of the Society for Experimental Biology and Medicine 204 4-29.

Lee PD, Giudice LC, Conover CA \& Powell DR 1997 Insulin-like growth factor binding protein-1: recent findings and new directions. Proceedings of the Society for Experimental Biology and Medicine 216 319-357.

Maures TJ \& Duan C 2002 Structure, developmental expression, and physiological regulation of zebrafish IGF binding protein-1. Endocrinology 143 2722-2731.

Maxwell A, Butterwick R, Yateman M, Batt RM, Cotterill A \& CamachoHubner C 1998 Nutritional modulation of canine insulin-like growth factors and their binding proteins. Journal of Endocrinology 158 77-85.

Mommsen TP \& Plisetskaya EM 1991 Insulin in fishes and agnathans: history, structure, and metabolic regulation. Reviews in Aquatic Sciences 4 225-259.

Moon TW 2001 Glucose intolerance in teleost fish: fact or fiction? Comparative Biochemistry and Physiology 129B 243-249.

Moon TW 2004 Hormones and fish hepatocyte metabolism: 'the good, the bad and the ugly!'. Comparative Biochemistry and Physiology 139B 335-345.

Norrelund H, Fisker S, Vahl N, Borglum J, Richelsen B, Christiansen JS \& Jorgensen JO 1999 Evidence supporting a direct suppressive effect of growth hormone on serum IGFBP-1 levels. Experimental studies in normal, obese and GH-deficient adults. Growth Hormone and IGF Research 952-60.

Park R, Shepherd BS, Nishioka RS, Grau EG \& Bern HA 2000 Effects of homologous pituitary hormone treatment on serum insulin-like growthfactor-binding proteins (IGFBPs) in hypophysectomized tilapia, Oreochromis mossambicus, with special reference to a novel 20-kDa IGFBP. General and Comparative Endocrinology 117 404-412.
Perez-Sanchez J, Weil C \& Le Bail PY 1992 Effects of human insulin-like growth factor-I on release of growth hormone by rainbow trout (Oncorhynchus mykiss) pituitary cells. Journal of Experimental Zoology 262 287-290.

Peterson BC \& Small BC 2005 Effects of exogenous cortisol on the GH/IGF-I/IGFBP network in channel catfish. Domestic Animal Endocrinology 28 391-404.

Pierce AL, Dickey JT, Larsen DA, Fukada H, Swanson P \& Dickhoff WW 2004 A quantitative real-time RT-PCR assay for salmon IGF-I mRNA, and its application in the study of GH regulation of IGF-I gene expression in primary culture of salmon hepatocytes. General and Comparative Endocrinology 135 401-411.

Pierce AL, Fukada H \& Dickhoff WW 2005a Metabolic hormones modulate the effect of growth hormone (GH) on insulin-like growth factor-I (IGF-I) mRNA level in primary hepatocyte culture. Journal of Endocrinology 184 341-349.

Pierce AL, Shimizu M, Beckman BR, Baker DM \& Dickhoff WW $2005 b$ Time course of the GH/IGF axis response to fasting and increased ration in chinook salmon (Oncorhynchus tshawytscha). General and Comparative Endocrinology 140 192-202.

Popovici RM, Lu M, Bhatia S, Faessen GH, Giaccia AJ \& Giudice LC 2001 Hypoxia regulates insulin-like growth factor-binding protein 1 in human fetal hepatocytes in primary culture: suggestive molecular mechanisms for in utero fetal growth restriction caused by uteroplacental insufficiency. Journal of Clinical Endocrinology and Metabolism 86 2653-2659.

Rand-Weaver M \& Kawauchi H 1992 A rapid procedure for the isolation of bioactive growth hormone. General and Comparative Endocrinology 85 341-345.

Scharf JG, Unterman TG \& Kietzmann T 2005 Oxygen-dependent modulation of insulin-like growth factor binding protein biosynthesis in primary culture of rat hepatocytes. Endocrinology 146 5433-5443.

Schmidt KE \& Kelley KM 2001 Down-regulation in the insulin-like growth factor (IGF) axis during hibernation in the golden-mantled ground squirrel, Spermophilus lateralis: IGF-I and the IGF-binding proteins (IGFBPs). Journal of Experimental Zoology 289 66-73.

Shepherd BS, Drennon K, Johnson J, Nichols JW, Playle RC, Singer TD \& Vijayan MM 2005 Salinity acclimation affects the somatotropic axis in rainbow trout. American Journal of Physiology - Regulatory Integrative and Comparative Physiology 288 R1385-R1395.

Shimizu M, Dickey JT, Fukada H \& Dickhoff WW 2005 Salmon serum $22 \mathrm{kDa}$ insulin-like growth factor-binding protein (IGFBP) is IGFBP-1. Journal of Endocrinology 184 267-276.

Shimizu M, Beckman BR, Hara A \& Dickhoff WW 2006 Measurement of circulating salmon IGF binding protein-1: assay development, response to feeding ration and temperature, and relation to growth parameters. Journal of Endocrinology 188 101-110.

Siharath K, Kelley KM \& Bern HA 1996 A low-molecular-weight (25-kDa) IGF-binding protein is increased with growth inhibition in the fasting striped bass, Morone saxatilis. General and Comparative Endocrinology 102 307-316.

Suwanichkul A, Allander SV, Morris SL \& Powell DR 1994 Glucocorticoids and insulin regulate expression of the human gene for insulin-like growth factor-binding protein-1 through proximal promoter elements. Journal of Biological Chemistry 269 30835-30841.

Thissen JP, Pucilowska JB \& Underwood LE 1994 Differential regulation of insulin-like growth factor I (IGF-I) and IGF binding protein-1 messenger ribonucleic acids by amino acid availability and growth hormone in rat hepatocyte primary culture. Endocrinology 134 1570-1576.

Unterman TG, Oehler DT, Murphy LJ \& Lacson RG 1991 Multihormonal regulation of insulin-like growth factor-binding protein-1 in rat H4IIE hepatoma cells: the dominant role of insulin. Endocrinology 128 2693-2701.

Wood AW, Duan C \& Bern HA 2005 Insulin-like growth factor signaling in fish. International Review of Cytology 243 215-285.

Received 31 May 2006

Received in final form 7 July 2006

Accepted 26 July 2006 